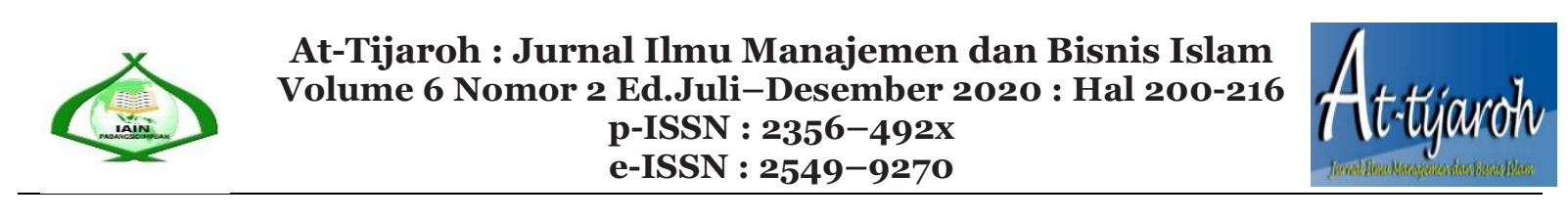

\title{
PERILAKU ETIS DITINJAU DARI KECERDASAN EMOSIONAL DAN RELIGIUSITAS
}

\author{
Aisah Amini' ${ }^{1}$ Dita Andraeny² \\ Institut Agama Islam Negeri Surakarta \\ Jl. Pandawa, Dusun IV, Pucangan, Kartasura, Sukoharjo, Jawa Tengah ${ }^{12}$ \\ 1aisahamini731@gmail.com \\ 2andrayanti88@gmail.com
}

\begin{abstract}
This study aims to analyze the effect of emotional intelligence and religiosity on ethical behavior of Sharia accounting students of the State Islamic Institute of Surakarta. This research uses primary data that are collected through questionnaires distributed to 91 students. The sampling technique used is purposive sampling method while analysis technique used is multiple linear regression analysis. The results of this research indicate that both emotional intelligence and religiosity have a positive and significant effect on the ethical behavior of Sharia Accounting Students. In addition the university must constantly endeavor to improve student's intellect, it will also need to instill religious values on students to establish a good student's personality and ethical conduct.
\end{abstract}

Keywords: emotional intelligence, religiosity and ethical behavior

\begin{abstract}
Abstrak
Penelitian ini bertujuan untuk meneliti pengaruh kecerdasan emosional dan religiusitas terhadap perilaku etis mahasiswa Akuntansi Syariah Institut Agama Islam Negeri Surakarta. Penelitian ini menggunakan data primer yang dikumpulkan melalui kuesioner yang didistribusikan kepada 91 mahasiswa. Teknik pengambilan sampel yang digunakan adalah purposive sampling sedangkan metode analisis data yang digunakan dalam penelitian ini adalah analisis regresi linear berganda. Hasil penelitian ini menunjukkan bahwa kecerdasan emosional dan religiusitas memiliki pengaruh positif dan signifikan terhadap perilaku etis mahasiswa Akuntansi Syariah. Oleh karena itu, selain perguruan tinggi harus terus berupaya meningkatkan intelektual mahasiswa, juga perlu menanamkan nilai-nilai religiusitas terhadap mahasiswa dalam rangka membentuk kepribadian mahasiswa yang baik dan memiliki perilaku etis.
\end{abstract}

Kata Kunci: kecerdasan emosional, religiusitas dan perilaku etis 


\section{1 | Perilaku Etis Ditinjau Dari Kecerdasan Emosional dan Religiusitas}

\section{PENDAHULUAN}

Perguruan tinggi hendaknya bukan hanya mampu menghasilkan mahasiswa berkualitas yang nantinya mampu bekerja secara profesional dan ahli dalam menjalankan kerjanya akan tetapi juga seharusnya diiringi dengan moral yang baik saat bekerja. Akan tetapi faktanya, masih banyak perguruan tinggi yang hanya memprioritaskan pendidikannya saja tanpa memperhatikan perilaku etis dari mahasiswa (Suyono, 2017).

Mahasiswa akuntansi adalah calon akuntan masa depan, untuk itu perlu adanya bekal pengetahuan tentang perilaku etis agar kelak ketika ia menjadi seorang akuntan dapat berperilaku jujur yang taat pada norma dan etika yang telah ditetapkan (Suyono, 2017). Sejalan dengan hasil penelitian (Arfaoui, dkk, 2016) yang mengatakan bahwa pendidikan etika dapat meningkatkan moral akuntan terutama dengan pelatihan prinsip-prinsip etika. Oleh karena itu, dalam rangka mengembalikan kredibilitas moral profesi akuntan, perguruan tinggi harus memiliki misi mengembangkan generasi akuntan yang berintegritas, profesional, dan bermoral (Ludigdo, 1999 dalam Hutahahean dan Hasnawati 2015).

Perguruan tinggi seharusnya mampu menciptakan akuntan masa depan yang dapat berperilaku etis, termasuk perguruan tinggi Islam. Perguruan tinggi Islam harus mampu menciptakan akuntan masa depan yang tidak hanya berintegritas, profesional dan bermoral namun juga harus berperilaku sesuai dengan nilai-nilai Islam (Cahyati, 2019). Terlebih lagi, menurut Rahma, Yulianti, \& Sofyani (2018), sebuah perguruan tinggi yang didasarkan pada aspek syariah akan memiliki dampak positif terhadap perilaku etis mahasiswa.

Logikanya, mahasiswa yang berada dalam perguruan tinggi Islam seharusnya lebih menanamkan nilai-nilai keislaman yang mana lebih mengutamakan kejujuran, integritas, kesopanan serta melakukan hal yang ma'ruf dan menjauhi yang munkar. Namun ternyata, pendapat diatas berbeda dengan hasil survei awal yang dilaksakan oleh peneliti pada mahasiswa akuntansi syariah di IAIN Surakarta. Hal ini dikarenakan pola pikir mahasiswa yang sudah berubah yaitu lebih mengutamakan IPK dibanding kejujuran. Hal ini membuat mahasiswa melakukan berbagai cara demi mendapatkan IPK tinggi meskipun dengan jalan yang salah.

Sebuah kecurangan seperti ini jika terus saja dibiarkan akan berdampak pada kualitas alumni yang akan memasuki dunia kerja. Kecurangan tersebut akan memupuk perilaku menyimpang pada diri seseorang bahkan ketika ia memasuki dunia kerja karena sudah melekat pada diri mahasiswa (Motifasari, Maslichah, \& Mawardi, 2019). Perguruan Tinggi Islam baik swasta maupun negeri seharusnya tidak hanya bertugas untuk mengembangkan kemampuan mahasiswa, akan tetapi juga mampu membentuk kepribadian yang baik pada diri mahasiswa (Motifasari et al., 2019), guna menyiapkan akuntan masa depan yang tidak mengabaikan perilaku etis seorang akuntan (Suyono, 2017). Oleh karena itu, penelitian ini 
akan meneliti pengaruh kecerdasan emosional dan religiusitas terhadap perilaku etis mahasiswa akuntansi syariah.

Menurut Tridhonanto \& Beranda (2010) seseorang yang kecerdasan emosionalnya tinggi memiliki kesadaran diri, kemampuan mengelola emosi, memotivasi diri, mampu berempati, dan mampu menjalin sosial dengan orang akan membuat seseorang dalam pengambilan keputusan lebih cenderung berperilaku etis (Agustini \& Herawati, 2013).

Hal ini didukung oleh penelitian Wiguna \& Suryanawa (2019) yang menyatakan bahwa kecerdasan emosional berpengaruh positif terhadap perilaku etis mahasiswa akuntansi. Bukti lain juga ditemukan dalam penelitian Apriono, Rispantyo, \& Widarno (2018), Adinda \& Rohma (2015) dan Lucyanda \& Endro (2012). Berbeda dengan hasil penelitian Wijayanti (2018) dan Tikollah, Triyuwono, \& Ludigdo (2006), hasilnya menunjukan bahwa kecerdasan emosional tidak mempengaruhi perilaku etis mahasiswa akuntansi.

Kecerdasan emosional dan Religiusitas menurut Wijayanti (2018) adalah sebuah kombinasi yang saling melengkapi guna membentuk sikap dan perilaku seseorang. Hal ini dikarenakan menurut Mazereeuw et al. 2014) religiusitas merupakan gabungan pengetahuan, agama dan perasaan yang akan menentukan tindakan seseorang. Menurut Emerson \& Mckinney (2010), seseorang yang memiliki religiusitas tinggi akan dapat berperilaku jujur, bertanggung jawab dan bertindak baik karena adanya keyakinan bahwa tindakannya akan dipertanggungjawabkan di dunia maupun akhirat.

Hasil penelitian Wiguna \& Suryanawa (2019) menyatakan bahwa religiusitas berpengaruh positif terhadap perilaku etis mahasiswa akuntansi. Bukti lain bahwa religiusitas berpengaruh terhadap perilaku etis juga ditemukan oleh Suyono (2017), Apriono et al., (2018), dan Keller et al., (2007). Namun, hasil yang berbeda juga ditemukan oleh Hutahahean \& Hasnawati (2015) yang menyatakan bahwa religiusitas tidak memiliki pengaruh yang signifikan terhadap perilaku etis mahasiswa akuntansi.

Berdasarkan latar belakang di atas, penulis tertarik untuk melakukan penelitian di IAIN Surakarta. Hal ini dikarenakan, IAIN Surakarta pada tahun 2018 berhasil menempati posisi pertama Perguruan Tinggi Agama Islam Negeri (PTKIN) kategori Institut di Indonesia versi Webometrics dikutip dari (http://www.iain-surakarta.ac.id) dan menjadi PTKIN yang paling diminati oleh calon mahasiswa baru jalur SPAN dengan jumlah 5.882 pendaftar (Purwaningrum, 2018). Oleh karena itu, untuk melihat bagaimana calon akuntan muslim dalam menjalankan kerjanya di masa depan, penulis tertarik untuk melakukan penelitian yang berjudul "Perilaku Etis Mahasiswa Akuntansi ditinjau dari Kecerdasan Emosional dan Religiusitas". 


\section{METODE PENELITIAN}

Penelitian ini merupakan penelitian kuantitatif yang dilakukan pada mahasiswa Akuntansi Syariah di Institut Agama Islam Negeri Surakarta. Jumlah populasi dalam penelitian ini adalah 953 mahasiswa. Teknik pengambilan sampel dalam penelitian ini adalah purposive sampling. Berikut adalah kriteria dalam pengambilan sampel yaitu mahasiswa Akuntansi Syariah IAIN Surakarta dan merupakan mahasiswa yang memiliki IPK diatas 3,30.

Penentuan ukuran sampel menggunakan rumus slovin (Agung, 2012):

$n=\frac{N}{1+N e^{2}}$

Keterangan:

n : Ukuran sampel

N : Ukuran Populasi

e : Persen kesalahan pengambilan sampel yang masih dapat ditolerir atau diinginkan dalam penelitian $(\mathrm{e}=10 \%)$

Perhitungan ukuran sampel:

$n=\frac{953}{1+953(0,1)^{2}}=91$

Dari hasil perhitungan di atas, maka ukuran sampel minimal yang digunakan dalam penelitian ini adalah 91 responden. Perhitungan ini diperoleh dari jumlah populasi mahasiswa jurusan akuntansi syariah yang berjumlah 953 orang. Penelitian dilakukan dengan cara penyebaran kuesioner melalui google form kepada 91 mahasiswa akuntansi syariah.

Tabel 1

Definisi Operasional Variabel

\begin{tabular}{|c|c|c|c|c|}
\hline No & $\begin{array}{c}\text { Variabel } \\
\text { Penelitian } \\
\end{array}$ & Definisi Operasional & Indikator & $\begin{array}{c}\text { Skala } \\
\text { Pengukuran } \\
\end{array}$ \\
\hline 1. & $\begin{array}{l}\text { Kecerdasan } \\
\text { emosional (X1) }\end{array}$ & $\begin{array}{l}\text { Kecerdasan } \text { emosional } \\
\text { adalah kemampuan } \\
\text { yang mengetahui } \\
\text { perasaan sendiri dan } \\
\text { perasaan orang lain, dan } \\
\text { menggunakan perasaan } \\
\text { sebagai alat untuk } \\
\text { menuntun pikiran dan } \\
\text { perilaku manusia dalam } \\
\text { rangka memecahkan } \\
\text { sebuah masalah (Meyer, } \\
\text { 20o8). }\end{array}$ & $\begin{array}{ll}\text { 1. } & \text { Kesadaran Diri } \\
\text { 2. Mampu } & \text { Mengelola Emosi. } \\
\text { 3. Memotivasi Diri. } \\
\text { 4. Mampu } \\
\text { Berempati. } \\
\text { 5. Mampu menjalin } \\
\text { sosial dengan } \\
\text { orang lain. } \\
\text { (Tridhonanto \& } \\
\text { Beranda, 2010) }\end{array}$ & $\begin{array}{l}\text { Skala Likert 1- } \\
5\end{array}$ \\
\hline
\end{tabular}




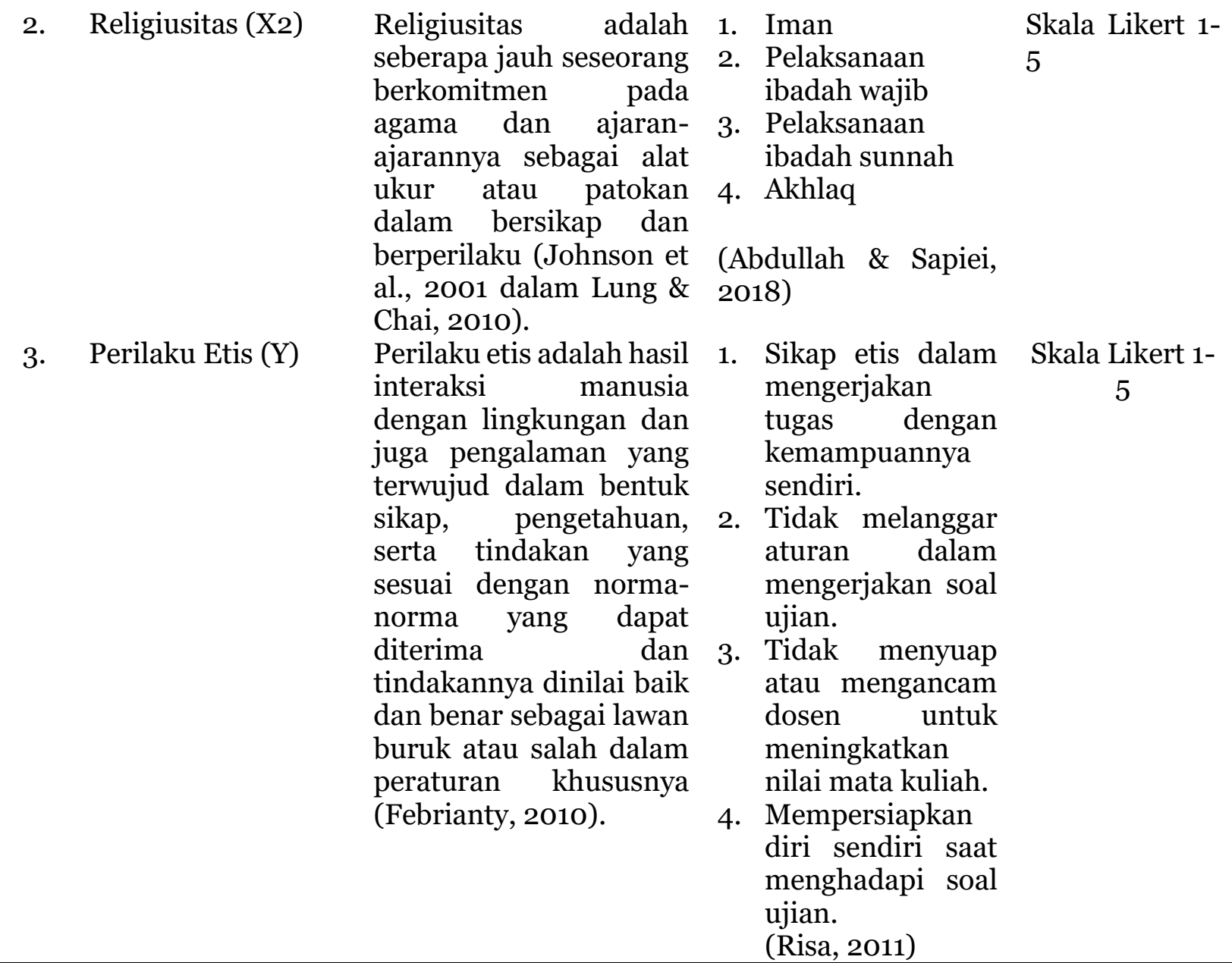

Jawaban atas item pertanyaan dalam kuesioner memiliki tingkatan skor yaitu (1) sangat tidak setuju; (2) tidak setuju; (3) kurang setuju; (4) setuju dan (5) sangat setuju.

Pengujian hipotesis dalam penelitian ini menggunakan "Analisis Regresi Linear Berganda”, yakni pengaruh variabel independen (kecerdasan emosional dan religiusitas) terhadap variabel dependen (perilaku etis mahasiswa akuntansi). Persamaan statistiknya adalah:

$\mathrm{Y}=\alpha+\beta_{1} \mathrm{X}_{1}+\beta_{2} \mathrm{X}_{2}+\mathrm{e}_{\mathrm{i}}$

Keterangan:

$Y$ : Perilaku Etis Mahasiswa Akuntansi

a: Konstanta,

$\beta$ : Koefisien

$\mathrm{X}_{1}$ : Kecerdasan emosional

$\mathrm{X}_{2}$ : Religiusitas

$e:$ Error 


\section{HASIL DAN PEMBAHASAN}

Pengumpulan data pada penelitian ini menggunakan kuesioner yang didistribusikan secara online melalui google formulir dengan memberikan kesempatan kepada sejumlah responden untuk mengisi kuesioner. Peneliti menyebarkan google formulir menggunakan media whatsapp dengan cara personal chat ataupun melalui grup whatsapp yang dilakukan pada bulan Desember 2019. Inisiatif ini diambil karena pada saat penelitian tersebut mahasiswa baru saja menjalani ujian akhir semester.

Responden yang digunakan dalam penelitian ini adalah mahasiswa jurusan Akuntansi Syariah semester 3, 5 dan 7 di Institut Agama Islam Negeri Surakarta, karena untuk semester 1 belum memiliki IPK. Berdasarkan hasil penyebaran kuesioner kepada responden melalui media online diperoleh 141 kuesioner yang terisi dan data yang diolah sejumlah 91. Dalam pengambilan sampel sejumlah 91 ini, peneliti menggunakan model stratified sampling, yaitu teknik penentuan sampel dengan memperhatikan strata di dalam populasi. Oleh karena itu, peneliti mengambil presentase yang sama besar yaitu masing-masing 33,3\% dari 91 jumlah sampel.

Adapun karakteristik responden yang digunakan dalam penelitian ini dilihat dari semester dan jenis kelamin.

Tabel 2

Tabulasi Data Responden berdasarkan Jenis Kelamin

\begin{tabular}{llcccc}
\hline & Frequency & Percent & $\begin{array}{c}\text { Valid } \\
\text { Percent }\end{array}$ & $\begin{array}{c}\text { Cumulative } \\
\text { Percent }\end{array}$ \\
\hline \multirow{2}{*}{ Valid } & Laki-laki & 13 & 14.3 & 14.3 & 14.3 \\
& Perempuan & 78 & 85.7 & 85.7 & 100.0 \\
\cline { 2 - 4 } & & & 100.0 & 100.0 & \\
\hline
\end{tabular}

Sumber: Data diolah

Berdasarkan tabel 2 dapat diketahui bahwa jumlah responden sebanyak 91 responden yang terdiri dari 13 responden berjenis kelamin laki-laki dan 78 responden berjenis kelamin perempuan. 
Tabel 3

Tabulasi Data Responden berdasarkan Semester

\begin{tabular}{llcccc}
\hline & Frequency & Percent & $\begin{array}{c}\text { Valid } \\
\text { Percent }\end{array}$ & $\begin{array}{c}\text { Cumulative } \\
\text { Percent }\end{array}$ \\
\hline \multirow{6}{*}{ Valid } & Semester 3 & 31 & 34.1 & 34.1 & 34.1 \\
& Semester 5 & 30 & 33.0 & 33.0 & 67.0 \\
\cline { 2 - 5 } & Semester 7 & 30 & 33.0 & 33.0 & 100.0 \\
& Total & 91 & 100.0 & 100.0 & \\
\hline
\end{tabular}

Sumber: Data diolah

Berdasarkan tabel 3 dapat diketahui bahwa jumlah responden sebanyak 91 mahasiswa akuntansi syariah IAIN Surakata, terdiri dari mahasiswa semester 3, semester 5 dan semester 7. Responden dari mahasiswa akuntansi syariah semester 3 sebanyak 31 mahasiswa $(34,1 \%)$, responden semester 5 sebanyak 30 mahasiswa $(33,0 \%)$ dan responden semester 7 sebanyak 30 mahasiswa $(33,0 \%)$.

Tabel 4

Statistik Deskriptif

\begin{tabular}{lcccccc}
\hline & N & Range & Minimum & Maximum & Sum & Mean \\
\hline Kecerdasan Emosional (X1) & 91 & 11 & 28 & 39 & 2983 & 32.78 \\
Religiusitas (X2) & 91 & 17 & 33 & 50 & 3984 & 43.78 \\
Perilaku Etis (Y) & 91 & 18 & 21 & 39 & 2887 & 31.73 \\
Valid N (listwise) & 91 & & & & & \\
\hline \multicolumn{1}{c}{ Sumber: } & & & & & &
\end{tabular}

Sumber: Data diolah

Berdasarkan tabel 4 di atas dapat diketahui jawaban responden dengan beberapa penjelasan berikut ini yaitu kuesioner pada variabel Kecerdasan emosional memiliki jumlah item pertanyaan sebanyak 8 dengan jawaban maksimal adalah 5 sehingga total jawaban maksimal adalah 40. Berdasarkan tabel di atas memiliki nilai mean 32,78 yang artinya ratarata mahasiswa Akuntansi Syariah menjawab kurang setuju pada item pertanyaan Kecerdasan Emosional, kuesioner pada variabel Religiusitas memiliki jumlah item pertanyaan sebanyak 10 dengan jawaban maksimal adalah 5 sehingga total jawaban maksimal adalah 50 . Berdasarkan tabel di atas memiliki nilai mean 43,78 yang artinya rata-rata mahasiswa Akuntansi Syariah menjawab setuju pada item pertanyaan Religiusitas, kuesioner pada variabel Perilaku Etis memiliki jumlah item pertanyaan sebanyak 8 dengan jawaban maksimal adalah 5 sehingga total jawaban maksimal adalah 40. Berdasarkan tabel di atas memiliki nilai 
mean 31,73 yang artinya rata-rata mahasiswa Akuntansi Syariah menjawab kurang setuju pada item pertanyaan Perilaku Etis.

\section{Pengujian dan Hasil Analisis Data}

\section{Uji Instrument Penelitian}

Uji Validitas Kecerdasan Emosional

Suatu kuesioner dikatakan valid jika memiliki nilai korelasi $r$ hitung $>r$ tabel dan sebaliknya jika $r$ hitung $<$ r tabel maka dikatakan tidak valid. Suatu instrument dikatakan valid apabila signifikansi < 0,05 atau $r$ hitung $>\mathrm{r}$ tabel (Nurhasanah, 2016).

Tingkat signifikansi yang digunakan dalam penelitian ini adalah sebesar $5 \%(0,05)$, untuk degree of freedom $(\mathrm{df})=\mathrm{n}$ (jumlah sampel) -2 (Astuti, 2018). Pada penelitian ini jumlah sampel (n) 91 dan besarnya df dapat dihitung $91-2=89$ dengan df 89 dan alpha 0,05 didapat $r$ tabel senilai 0,1735 .

Untuk melihat uji validitas dengan cara membandingkan nilai $r$ hitung dan $r$ tabel. Nilai $\mathrm{r}$ hitung dapat dilihat melalui kolom corrected item-total correlation sedangkan $\mathrm{r}$ tabel yaitu sebesar 0,1735. Berikut ini adalah perbandingan antara nilai $r$ hitung dengan $r$ tabel:

\section{Tabel 5}

\section{Perbandingan r hitung \& r tabel Variabel Kecerdasan Emosional}

\begin{tabular}{ccccc}
\hline Variabel & Item & r hitung & r tabel & Keterangan \\
\hline Kecerdasan & KE1 & 0,272 & 0,1735 & Valid \\
Emosional (X1) & KE2 & 0,389 & 0,1735 & Valid \\
& KE3 & 0,204 & 0,1735 & Valid \\
& KE4 & 0,181 & 0,1735 & Valid \\
& KE5 & 0,443 & 0,1735 & Valid \\
& KE6 & 0,262 & 0,1735 & Valid \\
& KE7 & 0,417 & 0,1735 & Valid \\
& KE8 & 0,397 & 0,1735 & Valid \\
\hline
\end{tabular}

\section{Sumber: Data diolah}

Dilihat dari tabel di atas menunjukan bahwa nilai $r$ hitung $>r$ tabel yang mengartikan bahwa semua item pertanyaan pada variabel kecerdasan emosional dikatakan valid.

\section{Uji Validitas Variabel Religiusitas (X2)}

Untuk melihat uji validitas dengan cara membandingkan nilai $r$ hitung dan $r$ tabel. Nilai $\mathrm{r}$ hitung dapat dilihat melalui kolom corrected item-total correlation sedangkan $\mathrm{r}$ tabel yaitu sebesar 0,1735. Berikut ini adalah perbandingan antara nilai $r$ hitung dengan $r$ tabel: 


\section{Tabel 6}

Perbandingan $\mathbf{r}$ hitung \& $\mathbf{r}$ tabel Variabel Religiusitas

\begin{tabular}{ccccc}
\hline Variabel & Item & r hitung & r tabel & Keterangan \\
\hline Religiusitas (X2) & R1 & 0,276 & 0,1735 & Valid \\
& R2 & 0,277 & 0,1735 & Valid \\
R3 & 0,498 & 0,1735 & Valid \\
R4 & 0,402 & 0,1735 & Valid \\
& R5 & 0,357 & 0,1735 & Valid \\
R6 & 0,554 & 0,1735 & Valid \\
& R7 & 0,515 & 0,1735 & Valid \\
R8 & 0,369 & 0,1735 & Valid \\
& R9 & 0,417 & 0,1735 & Valid \\
& R10 & 0,537 & 0,1735 & Valid \\
\hline
\end{tabular}

Sumber: Data diolah

Dilihat dari tabel di atas menunjukan bahwa nilai $r$ hitung $>r$ tabel yang mengartikan bahwa semua item pertanyaan pada variabel religiusitas dikatakan valid.

Uji Validitas Variabel Perilaku Etis (Y)

Untuk melihat uji validitas dengan cara membandingkan nilai $r$ hitung dan $r$ tabel. Nilai $\mathrm{r}$ hitung dapat dilihat melalui kolom corrected item-total correlation sedangkan $\mathrm{r}$ tabel yaitu sebesar 0,1735. Berikut ini adalah perbandingan antara nilai $r$ hitung dengan $r$ tabel:

Tabel 7

Perbandingan r hitung \& r tabel Variabel Perilaku Etis

\begin{tabular}{ccccc}
\hline Variabel & Item & r hitung & r tabel & Keterangan \\
\hline Perilaku Etis (Y) & PE1 & 0,473 & 0,1735 & Valid \\
& PE2 & 0,443 & 0,1735 & Valid \\
& PE3 & 0,572 & 0,1735 & Valid \\
& PE4 & 0,579 & 0,1735 & Valid \\
PE5 & 0,446 & 0,1735 & Valid \\
& PE6 & 0,354 & 0,1735 & Valid \\
& PE7 & 0,248 & 0,1735 & Valid \\
& PE8 & 0,442 & 0,1735 & Valid \\
\hline
\end{tabular}

Sumber: Data diolah

Dilihat dari tabel di atas menunjukan bahwa nilai $r$ hitung $>r$ tabel yang mengartikan bahwa semua item pertanyaan pada variabel perilaku etis dikatakan valid.

Uji Reliabilitas

Pengujian reliabilitas dilakukan dengan menggunakan koefisiensi alpha. Suatu kuesioner dikatakan reliabel atau handal jika nilai cronbach alpha di atas o,6 (Nurhasanah, 
2016). Berikut ini adalah hasil reliabilitas terhadap kuesioner pada masing-masing variabel penelitian.

\section{Tabel 8}

Hasil Uji Reliabilitas

\begin{tabular}{lccc}
\hline \multicolumn{1}{c}{ Variabel } & Cronbach's Alpha & Ketentuan & Kesimpulan \\
\hline Kecerdasan Emosional (X1) & 0,622 & $>0,60$ & Reliabel \\
Religiusitas (X2) & 0,750 & $>0,60$ & Reliabel \\
Perilaku Etis (Y) & 0,738 & $>0,60$ & Reliabel \\
\hline
\end{tabular}

Berdasarkan tabel di atas, nilai cronbach alpha untuk variabel kecerdasan emosional sebesar 0,622, dimana nilai cronbach alpha > 0,6. Oleh karena itu dapat disimpulkan bahwa pernyataan dalam kuesioner untuk variabel kecerdasan emosional dikatakan reliabel.

Berdasarkan tabel 8, nilai cronbach alpha untuk variabel religiusitas sebesar 0,750, dimana nilai cronbach alpha $>0,6$. Oleh karena itu dapat disimpulkan bahwa pernyataan dalam kuesioner untuk variabel religiusitas dikatakan reliabel.

Berdasarkan tabel 8, nilai cronbach alpha untuk variabel perilaku etis sebesar 0,738, dimana nilai cronbach alpha $>0,6$. Oleh karena itu dapat disimpulkan bahwa pernyataan dalam kuesioner untuk variabel perilaku etis dikatakan reliabel.

\section{Uji Asumsi Klasik}

Model regresi yang baik harus memenuhi syarat tidak adanya masalah asumsi klasik. Uji asumsi klasik dari masing-masing model meliputi uji normalitas, uji multikolinearitas dan uji heteroskedastisitas. Berikut adalah hasil uji asumsi klasik yang diolah oleh peneliti.

\section{Uji Normalitas}

Teknik pengujian yang dipakai dalam penelitian ini adalah One-Sample KolmogorovSmirnov Test (1-Sampel K-S). Ketentuan suatu model regresi berdistribusi secara normal apabila nilai probability dari Kolmogorov Smirnov > 0,05 (Ghozali, 2013). Berikut ini adalah tabel hasil uji normalitas One Sample Kolmogorov-Smirnov Test (K-S):

\section{Tabel 9}

Hasil Uji One Sample Kolmogorov-Smirnov Test (K-S)

\begin{tabular}{cccc}
\hline Keterangan & Asymp. Sig. (2-tailed) & Sig. & Keputusan \\
\hline Unstandardized Residual & 0,904 & 0,05 & Normal \\
\hline
\end{tabular}

Sumber: Data primer yang diolah, 2019 
Berdasarkan tabel 9 di atas, hasil uji kolmogorov-smirnov menunjukan bahwa besarnya nilai kolmogorov-smirnov adalah 0,568 dan nilai signifikan yang dilihat dari nilai asymp. Sig. (2-tailed) sebesar 0,904 > dari 0,05 maka dapat disimpulkan bahwa data dalam model penelitian ini telah berdistribusi dengan normal.

\section{Uji Multikolinearitas}

Uji multikolinearitas dapat dilakukan dengan 2 cara yaitu dengan melihat VIF (Variance Inflation Factors) dan nilai tolerance. Jika VIF $\geq 10$ dan nilai tolerance $\leq 0,10$ maka terjadi gejala mulitikolinearitas, begitupun sebaliknya (Ghozali, 2013). Berikut ini adalah tabel hasil uji multikolinearitas:

\section{Tabel 10}

\section{Hasil Uji Multikolinearitas}

\begin{tabular}{cccc}
\hline Variabel & VIF & Ketentuan & Keputusan \\
\hline Kecerdasan Emosional & 1,221 & $<10$ & Bebas Multikolinearitas \\
Religiusitas & 1,221 & $<10$ & Bebas Multikolinearitas \\
\hline
\end{tabular}

Sumber: Data diolah

Berdasarkan tabel 10, dapat diketahui bahwa nilai VIF yang ditampilkan pada tabel di atas, untuk variabel kecerdasan emosional dan religiusitas adalah 1,221 dan 1,221. Semua nilai VIF pada variabel independen kurang dari 10 sehingga dapat disimpulkan bahwa tidak terjadi masalah multikolinearitas. Nilai tolerance pada tabel di atas, untuk variabel kecerdasan emosional dan religiusitas adalah o,819 dan o,819. Terjadi multikolinearitas apabila tolerance kurang dari 0,1. Dari ketiga variabel tersebut nilai tolerance lebih dari o,1 sehingga tidak terjadi masalah multikolinearitas. Berdasarkan tabel di atas dapat disimpulkan bahwa semua nilai VIFnya kurang dari 10 dan nilai tolerance kurang dari o,1. Sehingga dapat disimpulkan bahwa tidak terdapat multikolinearitas antar variabel independen.

\section{Uji Heteroskedastisitas}

Uji heteroskedastisitas dilakukan dengan Uji Glejser. Syarat model agar tidak terjadi heteroskedastisitas adalah jika nilai signifikan seluruh variabel bebas > 0,05 (Ghozali, 2013). Berikut adalah tabel hasil uji heteroskedastisitas.

Tabel 11

Hasil Uji Heteroskedastisitas

\begin{tabular}{cccc}
\hline Variabel & Sig. & Ketentuan & Keputusan \\
\hline Kecerdasan Emosional & 0,664 & $>5$ & Bebas Heteroskedastisitas \\
\hline
\end{tabular}


211 | Perilaku Etis Ditinjau Dari Kecerdasan Emosional dan Religiusitas

\begin{tabular}{cccc}
\hline Religiusitas & 0,329 & $>5$ & Bebas Heteroskedastisitas \\
\hline
\end{tabular}

Sumber: Data diolah

Tabel 11 di atas, menunjukan bahwa nilai signifikansi variabel kecerdasan emosional (X1) dan religiusitas (X2) adalah o,664 dan 0,329. Berdasarkan hasil uji tersebut menunjukan bahwa semua nilai signifikansinya lebih besar dari 0,05. Sehingga variabel kecerdasan emosional dan religiusitas tidak terjadi gejala heteroskedastisitas.

\section{Uji Ketepatan Model}

\section{Uji F}

Uji F bertujuan untuk menguji variabel independen yang dilakukan secara simultan atau bersama-sama terhadap variabel dependen (Ghozali, 2013). Jika nilai signifikansi < 0,05 atau $\mathrm{F}$ hitung $>\mathrm{F}$ tabel maka variabel independen secara bersama-sama mempengaruhi variabel dependen. Berikut adalah hasil Uji F yang diolah menggunakan pengujian statistik SPSS 21:

Tabel 12

\section{Hasil Uji F}

\begin{tabular}{cccc}
\hline Uji & Sig. & Ketentuan & Keputusan \\
\hline Uji F & 0,000 & $>0,05$ & Terdapat Pengaruh
\end{tabular}

Sumber: Data diolah

Berdasarkan tabel 12 diatas, menunjukkan hasil uji simultan (uji F). dengan menggunakan signifikansi 5\%, hasil uji F pada tabel 12 bahwa nilai signifikansi adalah o,ooo atau kurang dari 0,05. Berdasarkan hasil uji ANOVA juga diperoleh nilai pembilang 2 (df1) dan nilai penyebut 88 (df2), maka diperoleh nilai $\mathrm{F}$ tabel adalah 3,10 sedangkan nilai $\mathrm{F}$ hitung 21,494. Nilai F hitung 21,494 lebih besar dari F tabel 3,10. Jadi berdasarkan hasil tersebut dapat disimpulkan bahwa model yang digunakan sudah tepat (fit).

\section{Uji Koefisien Determinasi $\left(R^{2}\right)$}

Uji koefisien determinasi $\left(\mathrm{R}^{2}\right)$ digunakan untuk mengetahui sejauh mana kemampuan model dalam menerangkan variasi variabel dependen (Ghozali, 2013). Dalam penelitian ini variabel independen yaitu kecerdasan emosional dan religiusitas. Sedangkan variabel dependennnya yaitu perilaku etis mahasiswa akuntansi. Berikut adalah hasil uji $\mathrm{R}^{2}$ dengan menggunakan pengujian statistik SPSS 21:

\section{Tabel 13}

Hasil Uji Koefisien Determinasi ( $\left.\mathbf{R}^{2}\right)$

\begin{tabular}{ccc}
\hline Uji & Adjusted R Square & Besaran Pengaruh \\
\hline $\mathrm{R}^{2}$ & 0,313 & 31,3 Persen
\end{tabular}

Sumber: Data diolah 
Berdasarkan tabel 13 di atas menunjukkan bahwa nilai Adjusted $R$ Square adalah o,313 atau $31,3 \%$. Sehingga dapat disimpulkan bahwa variabel kecerdasan emosional dan religiusitas dapat menerangkan $31,3 \%$ terhadap perilaku etis mahasiswa dan sisanya 68,7\% diterangkan atau dipengaruhi oleh variabel lain di luar model penelitian.

\section{Uji Regresi Linear Berganda}

Hasil pengolahan data dengan menggunakan pengujian statistik SPSS 21 diperoleh persamaan regresi linear berganda sebagai berikut:

\section{Tabel 14}

Hasil Uji Regresi Linear Berganda

\begin{tabular}{cc}
\hline Variabel & Koefisien \\
\hline \hline Kecerdasan Emosional (X1) & \\
Religiusitas (X2) & 0,471 \\
& 0,403 \\
\hline Sumber: Data diolah &
\end{tabular}

Berdasarkan tabel 14, maka diperoleh persamaan regresi linear berganda sebagai berikut:

$$
\mathrm{Y}=-1,375+0,471 \mathrm{KE}+0,403 \mathrm{R}+\mathrm{e}
$$

Berdasarkan hasil regresi pada tabel di atas nilai konstanta ( $\alpha$ ) diperoleh sebesar -1,375, berarti bahwa jika nilai variabel konstan (o) maka nilai perilaku etis mahasiswa akuntansi syariah di IAIN Surakarta sebesar $-1,375$.

\begin{tabular}{cccc} 
& \multicolumn{2}{c}{ Tabel 15 } & \\
& Hasil Uji Parsial & \\
\hline Variabel & T hitung & T tabel & Kesimpulan \\
\hline \hline & & & \\
Kecerdasan Emosional & 3,436 & 1,662 & Berpengaruh \\
Religiusitas & 3,592 & 1,662 & Berpengaruh \\
\hline Sumber : Data diolah & & & \\
\end{tabular}

Berdasarkan tabel diatas, berikut adalah hasil analisis hasil pengujian sebagai berikut:

\section{Pengaruh Kecerdasan Emosional terhadap Perilaku Etis Mahasiswa Akuntansi}

Berdasarkan hasil uji t di atas menunjukkan bahwa variabel kecerdasan emosional memiliki t tabel sebesar 1,662 yang diperoleh dari perhitungan $\mathrm{df}=\mathrm{n}-\mathrm{k}$ sehingga $91-3$ 


\section{3 | Perilaku Etis Ditinjau Dari Kecerdasan Emosional dan Religiusitas}

(variabel bebas dan terikat) $=88$ dan pada tingkat signifikansi $5 \%$ dengan satu arah. Berdasarkan perhitungan di atas, (X1) memiliki t hitung 3,436 lebih besar dari t tabel 1,662, artinya bahwa variabel kecerdasan emosional (X1) memiliki pengaruh positif terhadap perilaku etis mahasiswa akuntansi.

Adanya kecerdasan emosional pada diri mahasiswa akuntansi membuat mahasiswa akuntansi memiliki kemampuan dalam memahami perasaannya sendiri dan orang lain dan menggunakan perasaan dalam memecahkan sebuah masalah (Meyer, 2008). Terlebih lagi bagi mahasiswa yang berada dalam Perguruan Tinggi Islam yang mana didalamnya mempelajari etika Islam. Etika Islam mengajarkan bagaimana kita berhubungan dengan orang lain. Dalam Al-Qur'an surat Al-Maidah ayat 2 dijelaskan bahwa Allah SWT menyuruh seluruh umat manusia untuk saling tolong-menolong, namun dalam hal ini adalah tolong menolong dalam hal kebaikan bukan kejelekan (pelanggaran).

Menurut Simanjorang \& Sipayung (2012), dengan adanya kecerdasan emosional pada diri mahasiswa akuntansi akan membentuk bagaimana ia mampu mengendalikan dorongan hati, selalu berpikir positif, optimis dan bagaimana seseorang tersebut memiliki rasa percaya diri. Hal ini berkaitan erat dengan etika Islam yang telah mereka pelajari. Jika seorang mahasiswa memiliki komponen kecerdasan emosional di atas, maka semisal dalam mengerjakan ujian mereka lebih mengutamakan kejujuran sebagaimana yang terkandung AlQur'an surat Az-Zumar ayat 33-35.

Jadi dapat disimpulkan bahwa semakin tinggi kecerdasan emosional pada diri mahasiswa akuntansi, maka semakin baik perilaku etis mahasiswa akuntansi di sebuah Perguruan Tinggi. Hasil penelitian ini sejalan dengan penelitian yang dilakukan oleh Wiguna \& Suryanawa (2019), Apriono et al., (2018), dan Lucyanda \& Endro (2012).

\section{Pengaruh Religiusitas terhadap Perilaku Etis Mahasiswa Akuntansi}

Berdasarkan hasil uji t di atas menunjukkan bahwa variabel religiusitas (X2) memiliki t hitung sebesar 3,592 dengan $t$ tabel sebesar 1,662. Dimana $t$ hitung $>t$ tabel yang artinya bahwa variabel religiusitas (X2) memiliki pengaruh positif terhadap perilaku etis mahasiswa akuntansi.

Adanya religiusitas yang berupa Iman, melaksakan ibadah baik yang wajib ataupun sunnah dan akhlaq yang baik pada diri mahasiswa akuntansi akan dapat meningkatkan perilaku etis mahasiswa akuntansi (Abdullah \& Sapiei, 2018). Wahyuningsih (2018) mengatakan bahwa Islam sangat menjunjung tinggi etika sebagai bentuk fitrahnya manusia dengan mengutamakan kedamaian, kejujuran dan keadilan. Oleh karena itu, setiap orang termasuk mahasiswa juga harus mempertimbangkan semua perbuatan yang akan dilakukannya. Karena sesuai dengan parameter etika Islam yang mana disebutkan bahwa 
semua tindakan seseorang harus memiliki niatan yang baik karena Allah Maha Mengetahui apa yang dikerjakan oleh hambanya.

Selain itu, Islam memang memberikan kebebasan kepada setiap manusia untuk bertindak sesuai dengan keinginannya, namun semua itu ada balasannya. Jika seseorang melakukan tindakan baik maka ia akan mendapatkan balasan yang baik dari Allah. Namun, apabila seseorang melakukan tindakan buruk maka ia juga akan mendapatkan balasan buruk dari Allah. Semua tindakan yang kita lakukan pasti ada balasannya dan akan dipertanggungjawabkan di dunia maupun di akhirat.

Berdasarkan hal-hal di atas, seorang mahasiswa akan lebih cenderung untuk mempertimbangkan perilakunya dan selalu berpikir agar tidak melakukan tindakan yang menyimpang karena adanya keyakinan bahwa tindakannya akan dipertanggungjawabkan di dunia maupun akhirat (Emerson \& Mckinney, 2010). Jadi dapat disimpulkan bahwa semakin tinggi tingkat religiusitas pada diri mahasiswa akuntansi, maka semakin baik perilaku etis mahasiswa akuntansi di sebuah Perguruan Tinggi. Hasil penelitian ini sejalan dengan penelitian yang dilakukan oleh Suyono (2017), Wijayanti (2018) dan Keller et al., (2007).

\section{KESIMPULAN}

Penelitian ini bertujuan untuk mengetahui pengaruh kecerdasan emosional dan religiusitas terhadap perilaku etis mahasiswa akuntansi. Populasi dalam penelitian ini adalah mahasiswa akuntansi syariah Fakultas Ekonomi dan Bisnis Islam di IAIN Surakarta. Berdasarkan hasil analisis data dan uji hipotesis pada bab sebelumnya. Maka dapat disimpulkan bahwa; (1) Kecerdasan emosional berpengaruh positif terhadap perilaku etis mahasiswa akuntansi dan (2) Religiusitas berpengaruh positif terhadap perilaku etis mahasiswa akuntansi. Keterbatasan atas penelitian yaitu variabel kecerdasan emosional dan religiusitas hanya dapat menerangkan $31,3 \%$ terhadap perilaku etis mahasiswa. Sehingga kemungkinan masih terdapat variabel lain yang dapat memberikan pengaruh terhadap perilaku etis mahasiswa akuntansi syariah di IAIN Surakarta. Saran atas penelitian ini antara lain: (1) penelitian selanjutnya perlu menambahkan variabel-variabel lain yang dimungkinkan berpengaruh terhadap variabel dependen dan menggunakan alat analisis lain untuk mengetahui apakah hasil penelitian akan berbeda; (2) penelitian kedepannya bisa memperluas sampel penelitian dengan menggunakan responden mahasiswa akuntansi dari berbagai universitas baik negeri ataupun swasta yang terdapat kurikulum tentang nilai-nilai etika Islam di dalamnya sehingga diharapkan mahasiswa akuntansi syariah akan lebih berperilaku etis.

\section{DAFTAR PUSTAKA}

Abdullah, M., \& Sapiei, N. S. (2018). Do religiosity, gender and educational background influence zakat compliance? The case of Malaysia. International Journal of Social 
Economics, 45(8), 1250-1264. https://doi.org/10.1108/IJSE-03-2017-0091

Adinda, K., \& Rohman, A. (2015). Pengaruh kecerdasan emosional dan kecerdasan intelektual terhadap perilaku etis mahasiswa akuntansi dalam praktik pelaporan laporan keuangan. Diponegoro Journal of Accounting, 4(2006), 1-10.

Agung, A. A. P. (2012). Metodologi Penelitian Bisnis. Malang: UB Press.

Agustini, S., \& Herawati, N. T. (2013). Pengaruh kecerdasan intelektual, kecerdasan emosional, dan religiusitas terhadap mahasiswa S1 akuntansi Universitas Pendidikan Singaraja. E-Jurnal UNDIKSHA, 1-11.

Apriono, F. T., Rispantyo, \& Widarno, B. (2018). Pengaruh faktor individu dan diluar individu terhadap perilaku etis mahasiswa akuntansi. Jurnal Akuntansi Dan Sistem Teknologi Informasi, 14(April), 234-243.

Arfaoui, F., Damak-Ayadi, S., Ghram, R., \& Bouchekoua, A. (2016). Ethics Education and Accounting Students' Level of Moral Development: Experimental Design in Tunisian Audit Context. Journal of Business Ethics, 138(1), 161-173. https://doi.org/10.1007/s10551-015-2643-z

Cahyati, A. D. Akuntansi syariah terapkan nilai-nilai Islami. , (2019).

Emerson, T. L., \& Mckinney, J. (2010). Importance of Religious Beliefs to Ethical Attitudes in Business. Journal of Religion and Business Ethics, 1(2), 5.

Hutahahean, U. ., \& Hasnawati. (2015). Pengaruh gender, religiusitas dan prestasi belajar terhadap perilaku etis akuntan masa depan (studi pada mahasiswa akuntansi Perguruan Tinggi Swasta di wilayah DKI Jakarta). Jurnal Akuntansi Trisakti, 2(1), 49. https://doi.org/10.25105/jat.v2i1.4831

Keller, A. C., Smith, K. T., \& Smith, L. M. (2007). Do gender, educational level, religiosity, and work experience affect the ethical decision-making of U.S. accountants? Critical Perspectives on Accounting, 18(3), 299-314. https://doi.org/10.1016/j.cpa.2006.01.006

Lucyanda, J., \& Endro, G. (2012). Faktor-faktor yang mempengaruhi perilaku etis mahasiswa Universitas Bakrie. Media Riset Akuntansi, 2(2), 27-52.

Mazereeuw-van der Duijn Schouten, C., Graafland, J., \& Kaptein, M. (2014). Religiosity, CSR Attitudes, and CSR Behavior: An Empirical Study of Executives' Religiosity and CSR. Journal of Business Ethics, 123(3), 437-459. https://doi.org/10.1007/s10551-013-18473

Meyer, H. R. (2008). Manajamen dengan kecerdasan emosional. Bandung: Nuansa Cindekia.

Motifasari, E., Maslichah, \& Mawardi, C. M. (2019). Pengaruh Dimensi Fraud Triangel terhadap Perilaku Kecurangan Akademik pada Mahasiswa Akuntansi. E-JRA, 8(1), 6685 .

Purwaningrum, A. (2018). IAIN Surakarta Peringkat Pertama Paling Diminati Calon Mahasiswa Baru Se-Indonesia. Tribunnews. Retrieved from https://www.google.nl/amp/s/m.tribunnews.com/amp/regional/2018/o7/31/iainsurakarta-peringkat-pertama-paling-diminati-calon-mahasiswa-baru-se-indonesia

Rahma, N., Yulianti, R. T., \& Sofyani, H. (2018). Perilaku Etis Individu Dalam Pelaporan Keuangan: Peran Pendidikan Berbasis Syariah Dan Komitmen Religiusitas. Jurnal 
Akuntansi Dan Keuangan Islam, 6(1), 57-83. https://doi.org/10.35836/jakis.v6i1.9

Simanjorang, D., \& Sipayung, F. (2012). Pengaruh Kecerdasan Intelektual, Kecerdasan Emosional Dan Kecerdasan Spiritual Terhadap Sikap Etis Mahasiswa Manajemen Fakultas Ekonomi Universitas Sumatera Utara. Jurnal Ekonom, 15(2), 5-6.

Suyono, N. . (2017). Analisis Terhadap Perilaku Etis Akuntan Masa Depan (studi empiris pada Mahasiswa Akuntansi Universitas Sains Al-Qur'an). Jurnal Ekonomi Dan Teknik Informatika, 5(2), 1-6.

Tikollah, M. R., Triyuwono, I., \& Ludigdo, H. U. (2006). Pengaruh kecerdasan emosional, kecerdasan intelektual, religiusitas terhadap sikap etis mahasiswa akuntansi. Simposium Nasional Akuntansi (SNA) IX, Padang, 138-145. https://doi.org/10.1016/j.exger.2017.06.020

Tridhonanto, A., \& Beranda, A. (2010). Meraih sukses dengan kecerdasan emosional. Jakarta: PT Elex Media Komputindo.

Wiguna, I. K. R., \& Suryanawa, I. K. (2019). Pengaruh pemahaman kode etik akuntan, kecerdasan emosional, dan religiusitas terhadap perilaku etis mahasiswa akuntansi. EJurnal Akuntansi, 28(2).

Wijayanti, R. (2018). Studi determinan perilaku etis mahasiswa akuntansi. Jurnal Ekonomi Modernisasi, 14(3). 